\title{
生物活性リード分子の創製を指向したオリゴバレント対称性分子の探索合成
}

須本國弘

\section{Synthetic Studies on Developments for Bioactive New Leads of Oligovalent Symmetrical Molecules}

\author{
Kunihiro Sumoto \\ Faculty of Pharmaceutical Sciences, Fukuoka University; 8-19-1 Nanakuma, Jonan-ku, Fukuoka 814-0180, Japan.
}

(Received September 19, 2019)

\begin{abstract}
Interactions between carbohydrate-containing glycoproteins, proteoglycans, and glycolipids on the cell surface are important biological stages for the processes of bacterial or viral infection and tumor metastasis. Moreover, supramolecular interaction by macromolecules with two-fold $\left(C_{2}\right)$ or three-fold $\left(C_{3}\right)$ geometry is one of the common interactions in many important biological responses. To develop new multivalent symmetrical bioactive compounds or leads, we designed and synthesized several new molecules with these geometries and evaluated their bioactivities in an attempt to find new types of bioactive leads that may interfere with the sugar recognition process. We evaluated bioactivities including antibacterial, antiviral, and anticancer activities of targeted molecules in vitro using biological assay systems. Among the synthesized target derivatives examined, some bivalent symmetrical derivatives showed high levels of bioactivities. In this review, the author describes the results of synthesis of oligovalent symmetrical target compounds and some interesting guiding results of evaluation of their biological activities and structure-activity relationships.
\end{abstract}

Key words — oligovalent symmetrical molecule; hydantoin; triazane; phenylboronic acid; biological activity; sugar recognition

\section{はじめに}

細菌やウイルスによる感染あるいはがんの転移な ぞにおいて，細胞膜上に表出する糖鎖を有する糖夕 ンパクやプロテオグリカンあるいは糖脂質などの機 能は生物学的反応段階において極めて重要な役割を 演じる.さらに，これらの相互作用において生体マ クロ分子の $C_{2}$ (two-fold) あるいは $C_{3}$ (three-fold) 構造での相互作用は生体における重要なプロセスで しばしば認められる相互作用の形態である. ${ }^{1-8)}$

合成化学における触媒活性あるいは生物活性分子 を探索する医薬品化学領域の研究においても，オリ ゴバレントな活性発現部分を有する対称性分子は近 年多くの注目を集めている. 現在では分析化学の領 域などの研究へも広がりを見せる興味ある分子構造 の 1 つである.

福岡大学薬学部医薬品化学（干814-0180 福岡市城南区 七隈 8 丁目 19-1)

e-mail: kunihiro@fukuoka-u.ac.jp

本総説は, 2018 年度退職にあたり在職中の業績を中心

に記述されたものである。
生物活性化合物探索研究領域では未梢や中枢神経 関連薬の夕ならず抗菌薬や抗腫瘍活性薬物などの治 療薬における幅広い分野で 2 価あるいは 3 価などの オリゴバレント関連分子の有用性が報告されてい る．例えば，感染症治療薬分野あるいは抗がん活性 薬物などの研究 ${ }^{(-9)}$ において多くの新しいタイプの 2 価 $C_{2}$ 対称性化合物の報告がみられる。 また 2 価 あるいは 3 価などのオリゴバレント分子はシングル ドラッグ型の分子に比較して分子量は大きいが, 受 容体に対する親和性や活性の増強が期待される。才 リゴバレント分子を標的とする場合中分子領域化合 物となる可能性も大きく, 非ペプチド系中分子型化 合物としての側面からも興味がある. したがって生 物活性分子の探索研究に際して近年 $C_{2}$ あるいは $C_{3}$ などの対称性を有するオリゴバレント分子の有用性 が注目されるのは自然の流れであると推察され る. ${ }^{6-9)}$

近年，翻訳後修飾などにより生じる糖鎖の機能 は，生体反応をコントロールする核酸やタンパク質 に続く第三の生命鎖として生体で重要な機能を担う 
ことが明らかにされつつある。生体においてホモオ リゴマーで形成される多くのレセプター（受容体） や生体系の機能性マクロ分子の構造的形態として, $C_{2}$ あるいは $C_{3}$ などの対称性構造は頻繁に認められ ている. ${ }^{10)}$ また, マクロ分子の対称性を含めて, こ れらのマクロ分子とオリゴバレント分子の相互作用 の有用性（有効性）に対する理論的考察や解釈に関 する情報も蓄積されつつある. ${ }^{6,10-12)}$

このような背景を基にして, 抗菌活性, 抗ウイル ス (herpes simplex virus type 1; HSV-1) 活性あるい は腫瘍細胞増殖阻害活性などの生物活性を指標とし て新しいオリゴバレント生物活性分子の探索，こと に糖（鎖）に親和性を有する生物活性分子（リード 化合物）の探索を行い，最近までに興味あるオリゴ バレントな $C_{2}$ あるいは $C_{3}$ 対称性分子構造を有す るいくつかの新しい生物活性分子を見い出している (Fig. 1)。関連研究は糖（鎖）認識能を有する分子 という表現に着目すればレクチン様の糖（鎖）親和 性を示す生物活性合成物質の探索研究とも言える. また本稿で述べている対象とする分子はオリゴバレ ント構造分子であり，相互作用部位では多価効果1) が期待できる分子でもあり興味深い。本稿では生物 活性分子探索の一環として，これまで行ってきた糖 認識能を有する新規対称性活性分子の探索研究の一 部を簡単に紹介したい.

\section{1. ヒダントイン類13-19)}

抗菌活性化合物探索の一環として, Scheme 1 に 示したマロン酸エステル誘導体 (1) を原料とする経 路を用いて興味ある新規アミノ酸関連分子 $(\beta$-アミ ノアラニン類：2）を合成した. これらの $\beta$-アミノ アラニン類を用いて methicillin-resistant Staphylococcus aureus（MRSA）など各種の耐性菌に有効な リネゾリドのバイオアイソスター的関係にあると考 えられる分子への構造変換を試みた。オキサゾリジ ノン系化合物 $\mathbf{A}$ や5-アミノメチル置換ヒダントイ ン系化合物 B 関連誘導体（Fig. 2）の合成を行い化 合物の抗菌活性について検討した（オキサゾリジ） ン類 $\mathbf{A}$ 及びヒダントイン類 $\mathbf{B}$ の合成：Scheme 1 経 路参照).

シングルドラッグ型及びビバレント型オキサゾリ ジノン系誘導体 A では多くの化合物に特記すべき 抗菌活性はほとんど認められなかったが, バイオア イソスター的関係にある新規ヒダントイン系誘導体
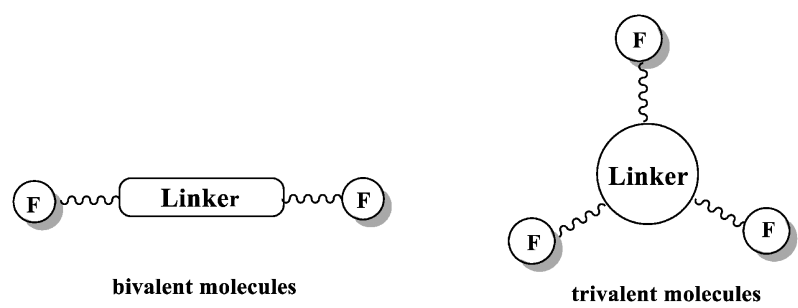

Fig. 1. Structural Models of Bivalent and Trivalent Molecules

(F) means a pharmacophore group.

B では一群の化合物にグラム陽性（S. aureus）あ るいはグラム陰性（Escherichia coli）菌に対する比 較的高い抗菌活性が確認できた。 ${ }^{17)}$ ヒダントイン系 の活性基本構造 $\mathbf{B}$ に着目，さらに各種のリンカー を有するビバレント構造の Twin-drug 型対称性分 子への構造変換, 得られたヒダントイン誘導体類の 生物活性について検討を加えた.

抗菌活性の増強を期待して合成した種々のリン カーを介するビバレント対称性ヒダントイン誘導体 のいくつかを一般構造式（B-1～B-3） で示した (Fig. 3). B-1 及び B-2 構造への変換についてはシ ングルドラッグ型 5-アミノメチル置換ヒダントイ ン系化合物 B の脱アミノ化により容易に得られる 5-メチレンヒダントイン（C）へのアミン類の付加 反応を利用する方法にて目的化合物を合成できた (Fig. 3). B-3 系の化合物については Scheme 2 に示 した方法で容易に合成できた（合成方法の詳細につ いて文献13,14,16) を参照されたい). 多くのビバレン ト構造ヒダントイン誘導体（B-1 や B-2）が特記す べき抗菌活性を示さず分子中のリンカーの結合様式 は活性発現に重要な役割を担っていることを確認で きた.リンカーの構造と結合様式が極めて特徵的で あるが，化合物 B-3 においては高い抗菌活性が認め られ活性発現に有効なリンカーとなることが判明し た.

関連誘導体中ビバレント誘導体 3a は最も高い抗 菌活性（S. aureus 及びE. coliに対する MIC は, それぞれ 0.024 及び $0.095 \mathrm{mM}$ ）を示した。 ヒダン トイン誘導体 $3 \mathbf{a}^{17)}$ の糖認識能についていくつかの 糖類関連物質を用いて検討した結果，化合物 $\mathbf{3 a}$ は 細胞接着やがんの転移に重要な役割を果たすと考え られているへパラン硫酸やデルマタンなどの硫酸化 多糖類 (sulfated glycosaminoglycans) ${ }^{15,16)}$ に対する 特異的親和性を確認できた。ビバレント化合物 3a 


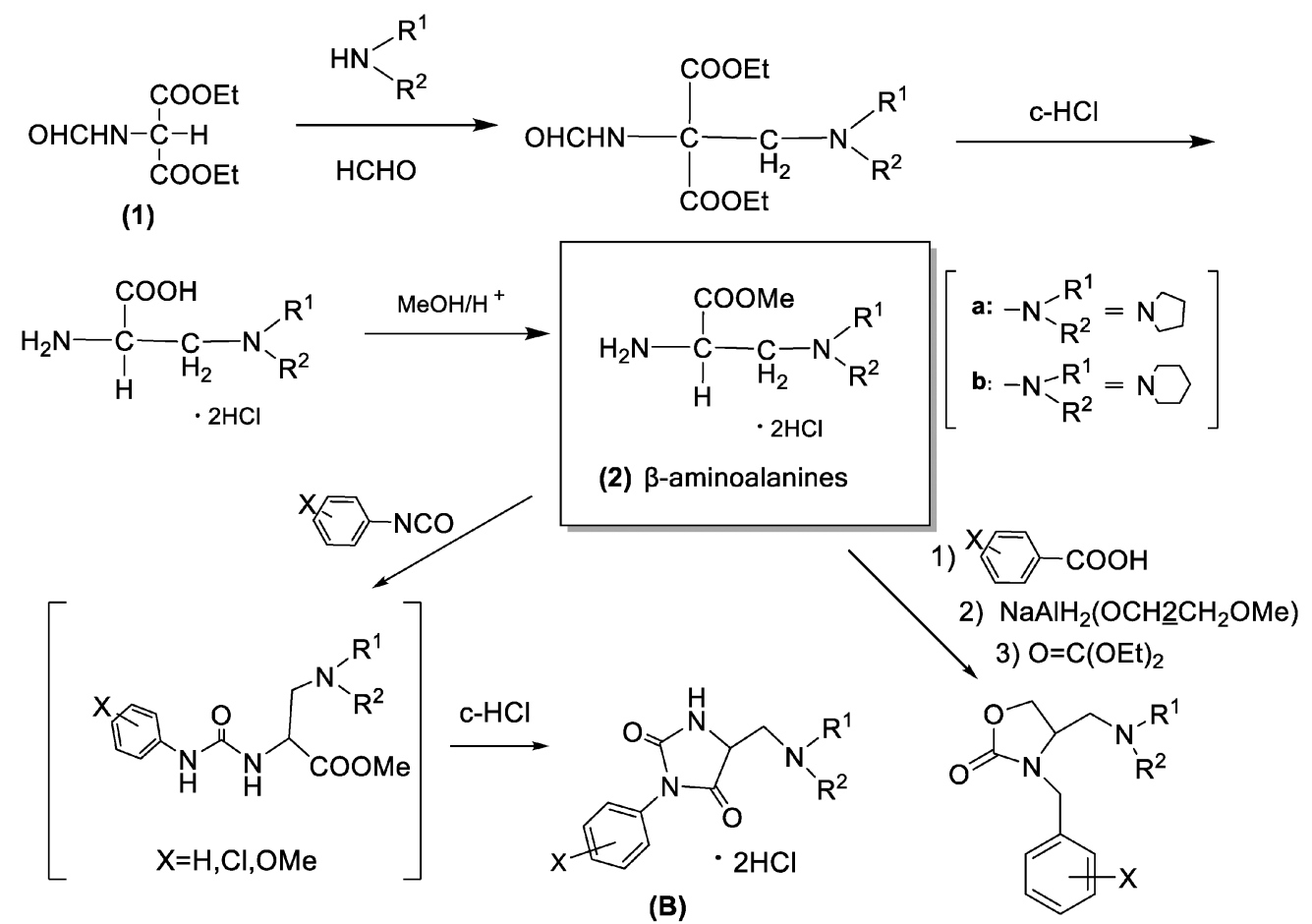

(A)

Scheme 1. Synthesis of $\beta$-Aminoalanines and Their Transformation to Single-drug Type Hydantoin Derivatives
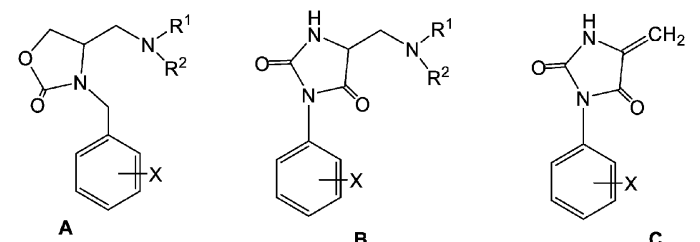

c

Fig. 2. General Structures of 4-Aminomethyloxazolizin-2ones (A) , 5-Aminomethylhydantoins (B) and 5-Methylenehydantoines $(\mathbf{C})$

の硫酸化多糖類を用いた等温滴定型熱量測定 (isothermal titration calorimetry; ITC)については, 後述する糖認識の項（Fig. 8）を参照されたい.

その後，化合物 3a を始めとするいくつかの B-3 タイプ結合様式の構造を有する対称性 Twin-drug 型（bivalent）ヒダントイン関連誘導体（Fig. 4) を用いて，2 種類のヒト由来腫瘍細胞（U251や KB3-1 細胞）を用いた。 MTT アッセイ法による腫 瘍細胞増殖抑制効果について活性評価を試みた。活 性評価の結果, いくつかのビバレントヒダントイン 誘導体について cisplatin の活性に匹敵する興味あ る細胞増殖抑制効果（抗がん活性）を見い出すこと ができた (Table 1). 19)

上記で述ベたビバレントヒダントイン系化合物を 構成する分子中の 2 つの 5 -置換ヒダントイン環は 5
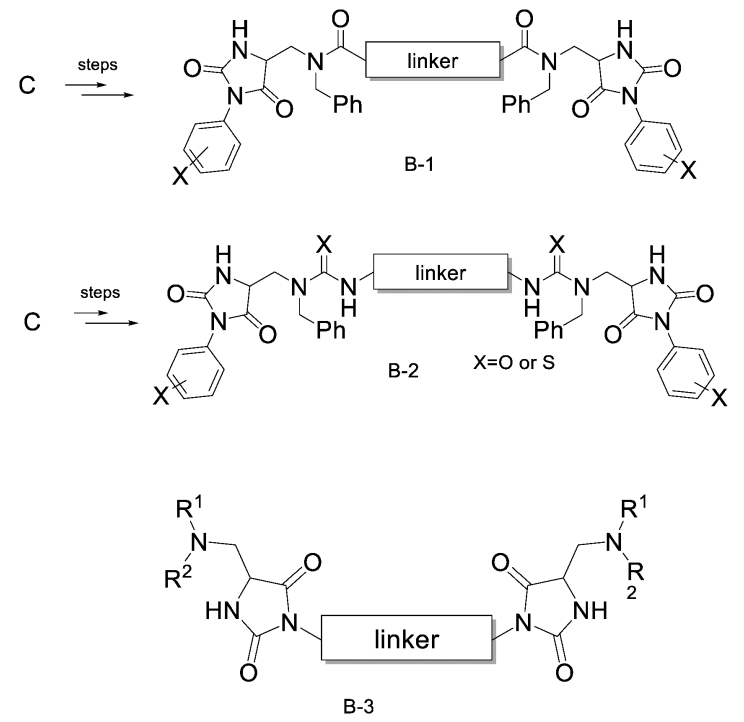

Fig. 3. General Structures of a Few Targeted Bivalent Symmetrical Hydantoin Derivatives (B-1, B-2 and B-3)

位に不斉中心を有する構造であることからこれらの 対称性 Twin-drug 型ヒダントイン関連誘導体には 理論的には 3 種の立体異性体 [すなわち，不斉中心 が同じ絶対配置（ $R, R$ 及び $S, S)$ を有する 2 種類 $C_{2}$-対称性化合物と不斉中心の絶対配置の異なる $C_{s}$-対称性の meso-体] が存在する. 3 種の異性体の 存在は HPLC で確認》できたが異性体の単離とそ 


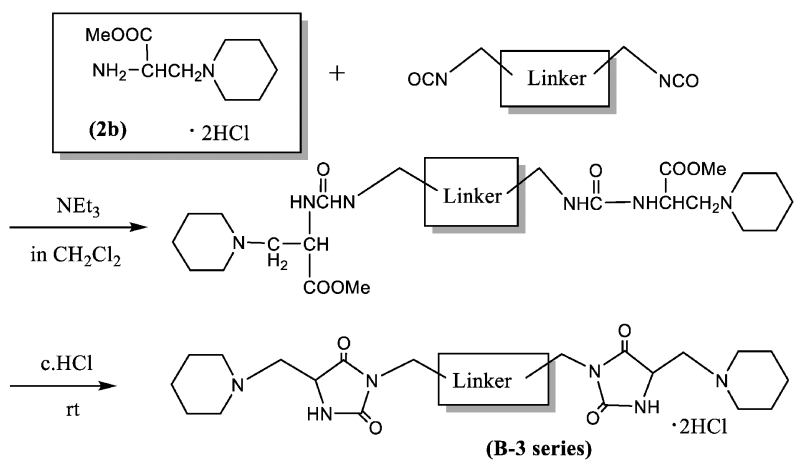

Scheme 2. Transformation to Bivalent Symmetrical Hydantoin Derivatives

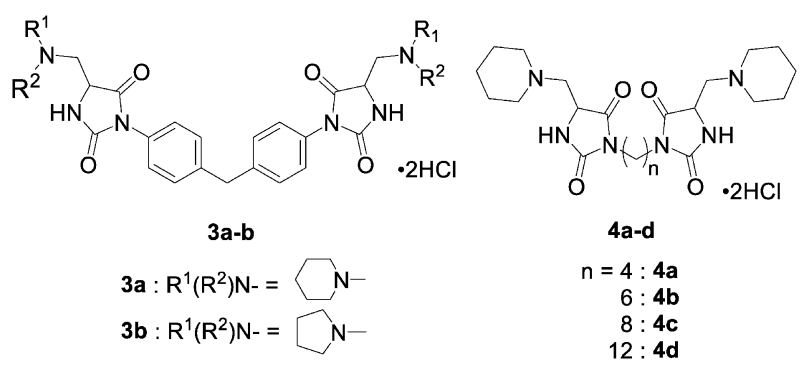

Fig. 4. Structures of Twin-drug Type Symmetrical 5-Substituted Hydantoin Derivatives

Table 1. Anticancer Activities ( $\left.\mathrm{IC}_{50}\right)$ of Target Bivalent Hydantoin Derivatives (3 and 4) against Human Brain Glioma Cells (U251 cells) and Human Carcinoma Cells (KB3-1 cells)

\begin{tabular}{lrr}
\hline \hline \multirow{2}{*}{ Compound } & \multicolumn{2}{c}{$\mathrm{IC}_{50}(\mu \mathrm{M})^{\mathrm{a}}$} \\
\cline { 2 - 3 } & $\mathrm{U} 251$ & $\mathrm{~KB} 3-1$ \\
\hline $\mathbf{3 a}$ & 1.63 & 9.85 \\
$\mathbf{3 b}$ & 0.46 & 5.21 \\
$\mathbf{4 a}$ & 4.49 & 26.08 \\
$\mathbf{4 b}$ & 1.99 & 10.41 \\
$\mathbf{4 c}$ & 1.05 & 9.42 \\
$\mathbf{4 d}$ & 7.00 & 7.12 \\
Cisplatin & 3.06 & 6.90 \\
\hline
\end{tabular}

${ }^{a} \mathrm{IC}_{50}$ : concentration that produces $50 \%$ inhibition of proliferation after $5 \mathrm{~d}$ of incubation. Reproduced with permission from Biol. Pharm. Bull. Vol. 42 No. 11 Pages 1953-1956. Copyright 2019 The Pharmaceutical Society of Japan.

の生物活性評価については現在検討中である.

\section{2. トリアジン類20-30)}

現在までにトリポーダル型分子の分子認識に関し てある種の陰イオンや陽イオンあるいは生体分子な どのいくつかの分子認識能が報告7)されている. 生 体における糖（鎖）関連分子の機能に干渉する（糖 認識能を有する) 生物活性化合物の探索研究の一環
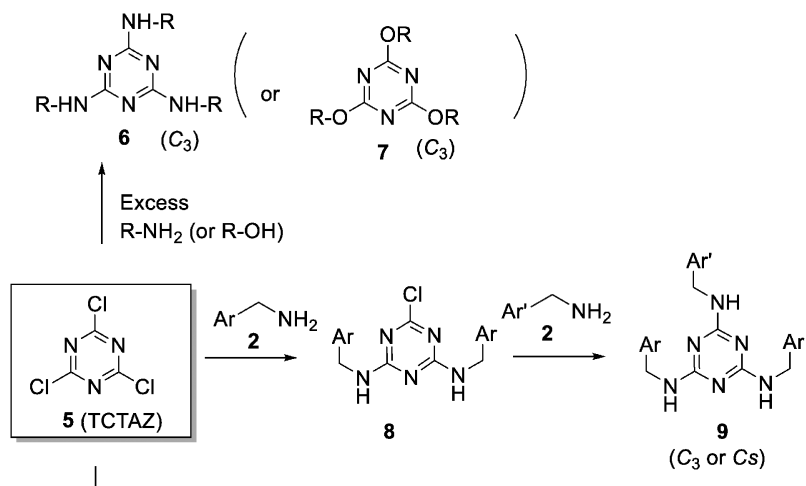

2-PrOH

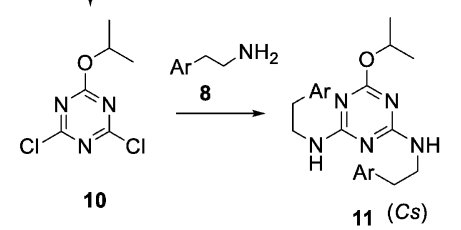

Scheme 3. Synthetic Pathway of Target 2,4,6-Trisubstituted Symmetrical TAZ Derivatives

として, トリポーダル受容体型分子の糖認識能を期 待して 1,3,5-トリアジン（1,3,5-triazine; TAZ）の $\mathrm{TAZ}$ 環の特異な対称構造に着目した。 TAZ 環を基 盤とする各種の 2,4,6-3 置換対称性 TAZ 類の合成 を行い，得られた化合物は抗ウイルス活性などを指 標として化合物の探索を展開した.

本研究では，研究の性質上，任意の置換基（特に アルコキシルやアミノ基など）を効率よく合成する 方法を確立することも重要な研究課題の一部であっ た。研究室で安価に入手可能な 2,4,6-トリクロロ TAZ（TCTAZ：5）を出発原料として，目的とす る 3 置換 TAZ 誘導体合成に必要な中間体(例えば,

Scheme 3 に示した化合物 $\mathbf{8}$ あるいは $\mathbf{1 0}$ などのよう なモノあるいはジクロロ TAZ 誘導体中間体）の効 率的な生成・単離を行い，最終工程におけるマイク ロウエーブの併用により， $C_{3}$ タイプのみならず $C_{s}$ タイプなどの標的 2,4,6-3 置換 TAZ 誘導体分子の 合成を収率よく達成する合成方法を確立できた（経 路概略を Scheme 3 に示した。合成方法の詳細につ いては文献18-25)参照).

Scheme 3 に示した経路を利用して多数の $C_{3}$ タイ プあるいは $C_{s}$ タイプの 3 置換 $\mathrm{TAZ}$ 誘導体を合 成，抗 HSV-1 活性について評価を加えた。 その結 果，Fig. 5 に示した $C_{3}$-対称性を有する 2 種の興味

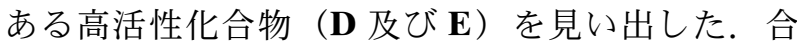
成した対称性 3 置換 TAZ 誘導体の各々の活性評価 
<smiles>CC(C)Oc1nc(OC(C)C)nc(OC(C)C)n1</smiles>

$\mathrm{EC}_{50}=1.87 \mu \mathrm{M}$ $\mathrm{IC}_{50}=479.8 \mu \mathrm{M}$

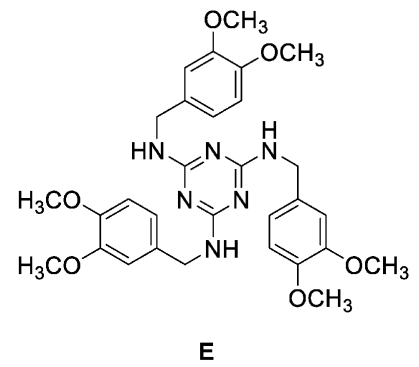

$\mathrm{EC}_{50}=0.98 \mu \mathrm{M}$ $\mathrm{IC}_{50}=292.2 \mu \mathrm{M}$
Fig. 5. Antiviral Active Tripodal Receptor Type TAZ Derivatives $(\mathbf{D}$ and $\mathbf{E})$

結果についてはこれまでの報告20-29)を参照して頂き たい. Figure 5 に示した $C_{3}$ タイプ TAZ 誘導体（D 及び E) ${ }^{23,25)}$ は極めて簡単な構造の TAZ 誘導体であ るが，高い抗ウイル活性を示し（anti-HSV-1 活性 がそれぞれ $\mathrm{EC}_{50}=1.87$ 及び $\left.0.98 \mu \mathrm{M}\right)$ ，またVero 細胞に対する細胞毒性（それぞれ $\mathrm{IC}_{50}=479.8$ 及び $292.2 \mu \mathrm{M})$ は低く選択係数（ $\mathrm{SI}=\mathrm{EC}_{50} / \mathrm{IC}_{50} ）$ の面 （D 及び E の SI はそれぞれ約 256 及び 298）からも 良好な結果が得られたことから，抗ウイルス活性化 合物探索におけるリード化合物として期待できる分 子であると推察できた.

化合物 $\mathbf{D}$ と $\mathbf{E}$ の構造的特徵として, 置換基の疎 水性や立体的嵩高さの差異も考慮する必要があるが,

TAZ 環 2,4,6 位に直結する 3 つテロ原子が化合 物 D の場合エーテル結合酸素原子-O-（水素結合受 容体：H-bond acceptor）であり，E の場合窒素原 子-NH-（水素結合供与体：H-bond donor）となっ ている点は大きな特徴であると言える。これらにつ
いてより詳細な知見を得るため，合成した TAZ 誘 導体 $\mathbf{D}$ 及び $\mathbf{E}$ の糖誘導体に対する糖認識能につい て ITC による検討を加えた。 その結果，化合物 D 及び $\mathbf{E}$ いずれも糖認識能を有するユニークな $C_{3}$ 対 称性 TAZ 誘導体であることを確認した。また，2 つの化合物の ITC 実験結果は糖に対する親和性に 関する熱力学的パラメーターが極めて異なる分子で あり選択性を有することも明らかにすることができ た。すなわちこの 2 つ小小分子 $(\mathbf{D}$ 及び $\mathbf{E})$ では 糖認識相互作用（複合体形成）における水素結合や 疎水性相互作用の重要な役割が大きく異なっている ことが示唆された（糖認識能の項 4-2. 参照). ${ }^{26)}$

これらの 2 種の活性分子をリードとして，さらに 別種の対称構造分子「ジアミノアルカン類（14）や tris-アミノエチルアミン（TAEA）など」24)を新た な対称性基盤リンカーとして分子中に組み込み $C_{2}$ あるいは $C_{3}$ タイプのオリゴバレントハイブリッド 型誘導体の合成を試みた（合成例については, Scheme 4 やScheme 5 参照). ${ }^{29,30)}$ 合成標的とする 分子の多くは，Lipinskiによる経験則「Rule of five」 における分子量（MW）が 500 を大きく超えいわゆ る中分子の範疇に属する興味あるオリゴバレント分 子と言える，近年，中分子に属するぺプチド類や天 然由来薬物の開発が注目されているが，今回標的と した誘導体の中分子としての特徵は非ぺプチド型の 対称性中分子31,32) であり，対称性を有する中分子の ため，NMR スペクトルなどの解析が通常の非対称 中分子と比べて極めて容易になるのも関連分子の特 徵であると考えている. 研究に係わつた学部学生の 知識でも NMR スペクトル帰属や構造確認の理解な
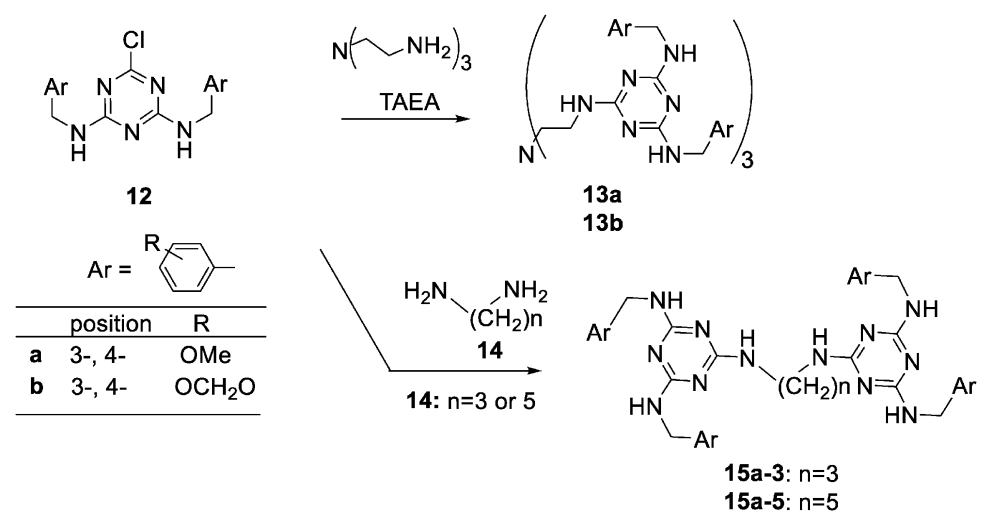

Scheme 4. Synthesis of $C_{3}$ - and $C_{2}$-Symmetrical Multivalent Hybrid-type TAZ Derivatives (13 and 15) Starting with Compound 12 and TAEA or Diaminoalkanes (14) 
(i)<smiles>CC(C)Oc1nc(Cl)nc(Cl)n1</smiles><smiles>CC(C)Oc1nc(Cl)nc(NC[Al])n1</smiles><smiles>CC(C)=O</smiles><smiles>CC(C)Oc1nc(Cl)nc(OC(C)C)n1</smiles>

19

20

(ii)

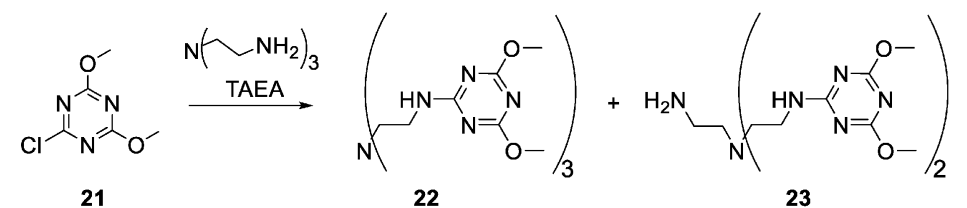

21

22

23

(iii)

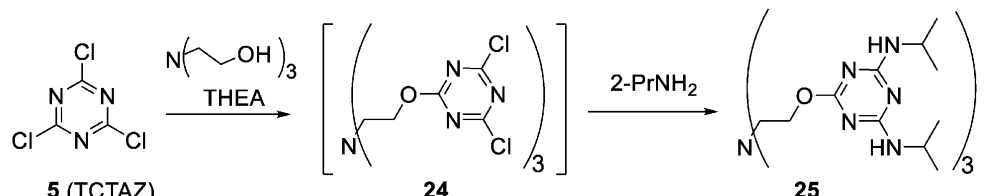

Scheme 5. Synthesis of Target Multivalent TAZ Derivatives

(i) Stepwise synthesis of $C_{3}$-symmetrical multivalent hybrid-type TAZ derivatives (18 and 20) starting from a monoisopropoxy-substituted TAZ derivative (16). (ii) Synthesis of a $C_{3}$-symmetrical hybrid-type TAZ derivative 22 from a dimethoxy-substituted TAZ derivative 21 and TAEA. (iii) Two-step synthesis of a $C_{3}$-symmetrical hybrid-type TAZ derivative 25 from TCTAZ (5).

ぞ比較的容易であった.

Scheme 4 や Scheme 5 に従って合成したアルコキ シ基やアミノ基で置換された TAZ 環を有するハイ ブリッド型 TAZ 誘導体（例えば，化合物 18， 20, 22, 23, 25 など）の抗 HSV-1 活性評価の結果，マル チバレント $C_{3}$ タイプハイブリッド型 TAZ の多く には抗 HSV-1 活性はほとんど認められなかった. しかしながら，鎖状メチレンをリンカーとした $C_{2}$ 対称性ハイブリッド型 TAZ 誘導体 15a-3（Fig. 6) は細胞毒性が少ない（ $\mathrm{IC}_{50}>200 \mu \mathrm{M} ）$ にもかかわ らず比較的高い抗 HSV-1 活性 $\left(\mathrm{EC}_{50}=19.1 \mu \mathrm{M}\right)$ を発現し，本系統のハイブリッド型中分子 $\mathrm{TAZ}$ 誘 導体のシードとして期待が持てる化合物であっ た. ${ }^{29)}$

本系列のハイブリッド型 $C_{2}$ 対称性 TAZ 誘導体 はリンカー部分の更なる変換が必要であると判断, その後リンカーを改変したいくつかの関連誘導体の 合成を試みより高い抗 HSV-1 活性 $\quad\left(\mathrm{EC}_{50}=7.6\right.$ $\left.\mu \mathrm{M}, \quad \mathrm{IC}_{50}>200 \mu \mathrm{M}\right)$ 化合物 15a-4 を見い出すに至 つている（Fig. 6). ${ }^{30)}$ 非ぺプチド型抗ウイルス活性 中分子としての構造変換やオリゴバレント型中分子
としての糖認識能の評価確認については今後の課題 であると考えている.

\section{3. ボロン酸類 ${ }^{33-43)}$}

種々の天然由来の $C_{2}$ 対称性生物活性分子の各種 感染症治療薬や抗がん活性分子創製を期待して，近 年多くの研究が報告されている. ${ }^{33)}$

ボロン酸誘導体の一般的な化学的性質としては糖 あるいは糖鎖に含有される 1,2-ジオール構造と特異 的に反応して環状のボロン酸エステル類を形成する ことはよく知られている $(\mathbf{F} \rightleftharpoons \mathbf{G} ;$ Scheme 6). また生成する環状ボロン酸エステル類は対応するボ ロン酸と含水系で化学的平行状態にあることもよく 知られている.

近年，ボロン酸誘導体類は有機合成における触媒 などとしての利用のみならず，糖類分析化学におけ る生体中の糖類の検出（血糖值測定などの糖セン サー）への利用などの研究例 ${ }^{34)} も$ みられ、このよ うな糖類に対する高い親和性の分析化学への応用あ るいは生物活性化合物の探索研究は近年に至って始 まった新しい領域と言える. ${ }^{35)}$ ホウ素原子を含有す るボロン酸誘導体類はいわゆるボロノレクチン 


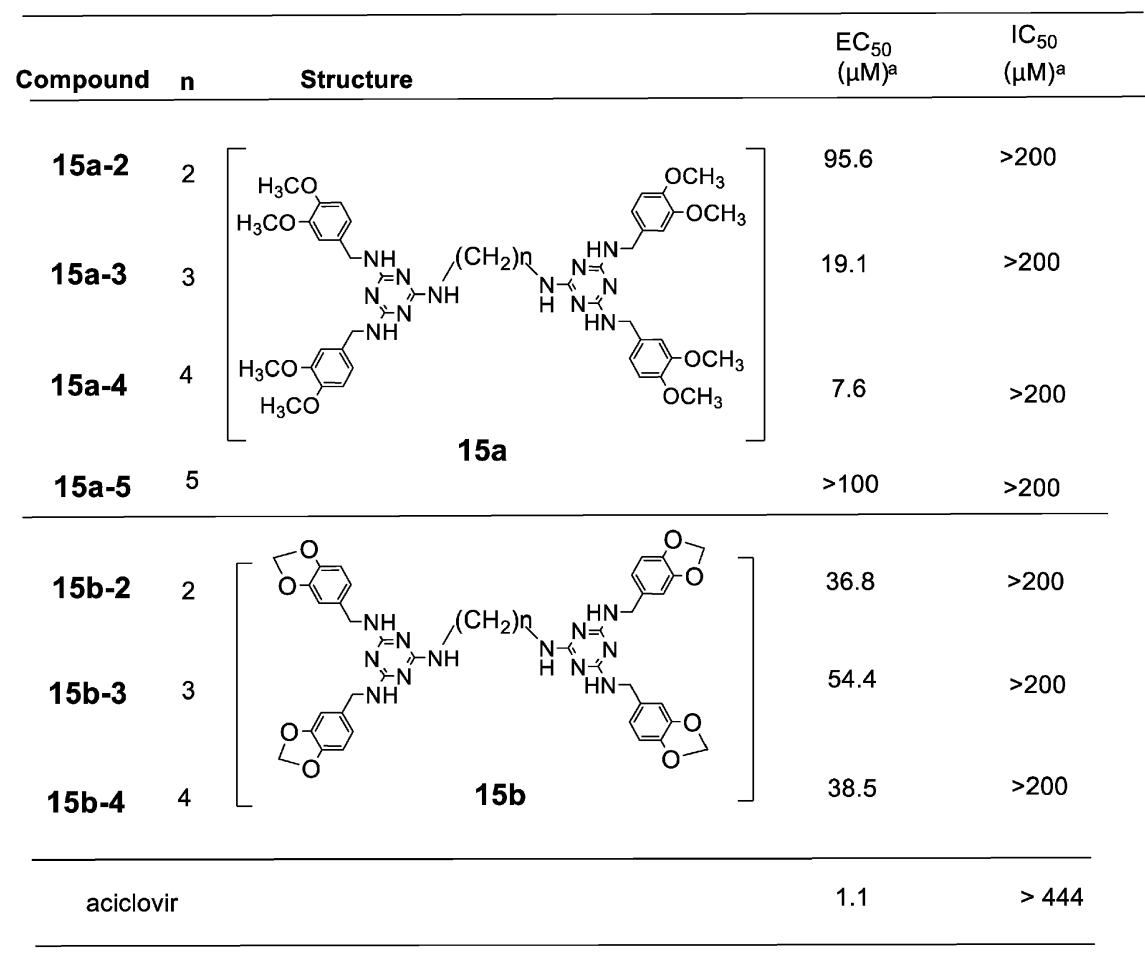

${ }^{a}$ Data were taken from references 29 and 30 .

Fig. 6. Anti-HSV-1 Active Hybrid-type Oligovalent $C_{2}$-Symmetrrical TAZ derivatives (15)

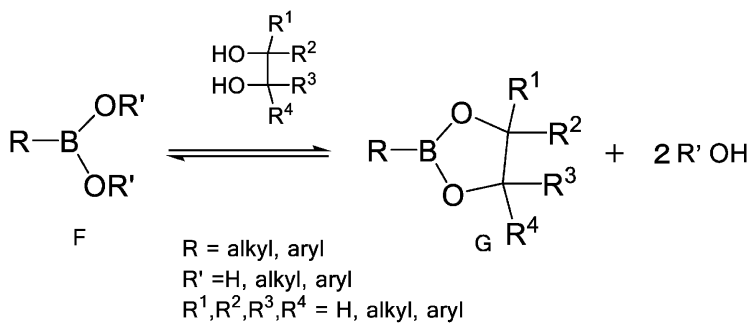

Scheme 6. Reactions of Boronic Acid Derivatives with 1,2Diol Functionalities

（boronolectins）と呼ばれる範疇に属する化合物で, 糖鎖に干渉する機能が期待できる極めて興味ある分 子種であり，新しい作用機序を有する新規生物活性 リード化合物の創製も期待される.

$o-, m-, p-ア ミ ノ$ 置換フェニルボロン酸誘導体 （例えば. 化合物 26: Table 2) を出発原料として, 種々のタイプの鎖状リンカーを有するビバレントな $C_{2}$ 対称性あるいはトリバレント $C_{3}$ 対称性ボロン酸 誘導体（3-置換ベンゼンやシクロヘキサン誘導体を 標的分子のテンプレートとして利用）の合成を試 み, 得られた化合物の新規な生物活性発現分子種と しての可能性を検討すべく研究に着手した.

合成した $C_{2}$ 対称性フェニルボロン酸エステル誘
導体のいくつかを Table 2 に示した. Table 2 に記 載したビバレント $C_{2}$ 対称性ボロン酸誘導体の多く は抗菌活性や抗ウイルス活性あるいは Vero 細胞に 対する細胞毒性など幅広く生物活性を発現する分子 種であることを確認した。 また，本系列化合物の抗 菌，抗ウイルスを含めた生物活性においてリンカー 部のメチレン鎖の長さが活性の発現に重要な因子で あることを確認できた。 Table 2 に記載した以外に も多くの $C_{2}$ あるいは $C_{3}$ 対称性ボロン酸関連誘導 体合成を試み生物活性評価を行った。関連誘導体の 合成及び得られた化合物の抗菌活性や抗ウイルス活 性などについては文献として記載した報告 ${ }^{36-43)}$ を参 照して頂きたい.

抗がん活性発現にオリゴバレント構造（例えば $C_{3}$ 対称性など）の有効性が報告21)されていること から, 数種の $C_{2}$ あるいは $C_{3}$ 対称性ボロン酸誘導 体の抗腫瘍活性について, ヒト由来腫瘍細胞 （U251 及び KB3-1）に対する細胞増殖阻害効果に ついて MTT アッセイ法を用いて活性評価 ${ }^{43)}$ を試み た．検討したオリゴバレントフェニルボロン酸誘導 体の構造式及び評価結果を Fig. 7 と Table 3 に示し た. 
Table 2. $\quad C_{2}$-Symmetrical Bivalent Phenylboronic Acid Pinacol Esters and Their Biological Activities

\begin{tabular}{|c|c|c|c|c|c|c|}
\hline \multicolumn{3}{|c|}{$\begin{array}{c}26 \\
2.0 \text { equiv. }\end{array}$} & 1.0 equiv. & $\underset{\mathrm{CH}_{2} \mathrm{Cl}_{2}, \mathrm{rt}, 18 \mathrm{~h}}{\stackrel{\mathrm{h}}{\mathrm{N}} \text { (3.0 equiv. }}$ & $\mathrm{PinB}-\xi=$ & ${ }_{\xi} 8^{H}$ \\
\hline & \multirow{2}{*}{$n$} & \multirow{2}{*}{ Yield (\%) } & \multicolumn{2}{|c|}{$\operatorname{MIC}[\mu \mathrm{M}(\mu \mathrm{g} / \mathrm{mL})]$} & $\mathrm{EC}_{50}(\mu \mathrm{M})$ & $\mathrm{IC}_{50}(\mu \mathrm{M})$ \\
\hline & & & S. aureus & E. coli & Anti-HSV-1 activity & Cytotoxic activity \\
\hline $28 \mathrm{a}$ & 4 & 82 & $\geqq 233.4(\geqq 128)$ & $\geqq 233.4(\geqq 128)$ & $>100$ & $>200$ \\
\hline $28 b$ & 5 & 62 & $227.6(128)$ & $227.6(128)$ & 62.7 & $>200$ \\
\hline $28 \mathrm{c}$ & 6 & 98 & $111.1(64)$ & $\geqq 222.1(\geqq 128)$ & 38.6 & $>200$ \\
\hline 28d & 7 & 67 & $27.1(16)$ & $216.8(128)$ & 8.0 & 25.2 \\
\hline $28 \mathrm{e}$ & 8 & 85 & $\geqq 211.8(\geqq 128)$ & $\geqq 211.8(\geqq 128)$ & 41.1 & $>200$ \\
\hline
\end{tabular}

Cited and modified from Furutachi M., et al., Heterocycles, 94 (9), 1748-1758 (2017).

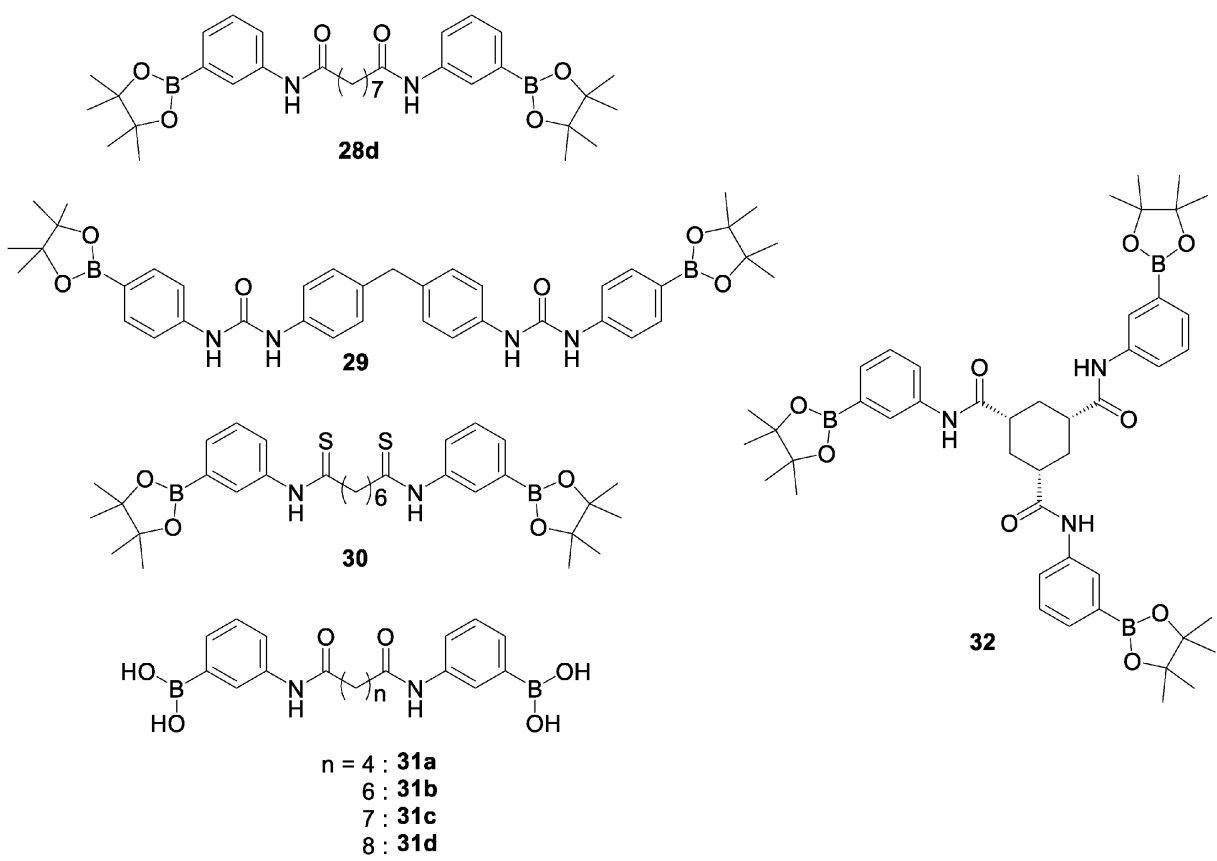

Fig. 7. Molecular Structures of Targeted $C_{2}$ - and $C_{3}$-Symmetrical Oligovalent Phenylboronic Acid Derivatives

Table 3 中のビバレント $C_{2}$ 対称性フェニルボロ ン酸誘導体では遊離ボロン酸 31d が最も高い増殖 阻害活性を示した。特にKB3-1 株に対する活性は 対照薬とした cisplatin より高い増殖抑制活性が認 められたことは特記すべき結果であると考えてい る. 評価結果から本系列化合物の活性発現に際して リンカー部分構造の重要性が示唆されたことから, リンカー鎖部分構造の調節によりさらに高活性の腫 瘍細胞増殖抑制化合物への展開が期待できる．化合 物 31d は抗ウイルス (anti-HSV-1) $\quad\left(\mathrm{EC}_{50}>100 \mu \mathrm{M}\right)$ 活性や細胞毒性（Vero 細胞）（ $\mathrm{IC}_{50}>200 \mu \mathrm{M} ） も$
少なくU251やKB3-1 細胞に対する選択性も高い ことから，ビバレントフェニルボロン酸誘導体の リード化合物として期待できる分子種と考えてい

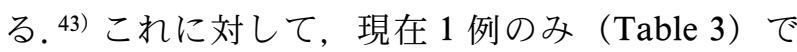
あるが， $C_{3}$ タイプのトリバレントフェニルボロン 酸ピナコールエステル誘導体 32 は KB3-1 にのみ活 性が高く $\left(\mathrm{IC}_{50}=26.3 \mu \mathrm{M}\right)$, 今後 $\mathrm{KB} 3-1$ 細胞に対 する選択的増殖抑制活性を有する分子への構造変換 展開が期待できると考えている．糖（グルコース） センサーへの応用研究 ${ }^{34)}$ においてもビバレント分子 の糖選択性や感度の向上が報告されていることから 
Table 3. Anticancer Activities ( $\left.\mathrm{IC}_{50}\right)$ of Target Molecules against Human Brain Glioma Cells (U251 cells) and Human Carcinoma Cells (KB3-1 cells), Cytotoxicities $\left(\mathrm{IC}_{50}\right)$ against Vero Cells and Anti-HSV-1 Activities $\left(\mathrm{EC}_{50}\right)$

\begin{tabular}{lccccc}
\hline \hline \multirow{2}{*}{ Compound } & \multicolumn{3}{c}{$\mathrm{IC}_{50}(\mu \mathrm{M})^{\mathrm{a}}$} & & $\mathrm{EC}_{50}(\mu \mathrm{M})$ \\
\cline { 2 - 3 } \cline { 6 - 6 } & Vero cells & $\mathrm{U} 251$ & $\mathrm{~KB} 3-1$ & & Anti-HSV-1 \\
\hline 28d & 25.2 & $>100$ & $>100$ & & 8.0 \\
$\mathbf{2 9}$ & 28.8 & 44.4 & $>100$ & $>100$ \\
30 & 14.8 & $>100$ & $>100$ & & 4.0 \\
31a & 76.2 & $>100$ & $>100$ & $>100$ \\
31b & $>200$ & $>100$ & 33.9 & & $>100$ \\
31c & 5.43 & 39.6 & 32.5 & $>100$ \\
31d & $>200$ & 19.0 & 3.78 & $>100$ \\
32 & $>200$ & $>100$ & 26.3 & 65.2 \\
Cisplatin & - & 3.06 & 6.90 & - \\
\hline
\end{tabular}

${ }^{\mathrm{a}} \mathrm{IC}_{50}$ : concentration that produces $50 \%$ inhibition of proliferation after $5 \mathrm{~d}$ of incubation. Reproduced with permission from Biol. Pharm. Bull. Vol. 42 No. 5 Pages 833-836. Copyright 2019 The Pharmaceutical Society of Japan.

更なる研究の発展を期待している.

\section{4. 活性化合物の糖認識能}

4-1. ヒダントイン類関連誘導体中高い抗菌 活性を示したヒダントイン誘導体 $\mathbf{3 a}$ の糖認識能に ついての熱力学的知見を得ることを目的として，い くつかの糖関連化合物を用いて ITC 実験を用いて 検討を加えた. ${ }^{15,16)}$ その結果，ビバレントヒダント イン誘導体 3a は細胞の接着やがんの転移に重要な 役割を果たすと考えられているへパラン硫酸やデル マタンなの硫酸化多糖類（sulfated glycosaminoglycans） ${ }^{44)}$ に対して親和性（複合体形成能）を有する ことを確認でき，このような硫酸化多糖類との相互 作用が抗菌活性や抗腫瘍活性（細胞増殖阻害活性） の機序の一部として関与していることが示唆された (Fig. 8).（熱力学的パラメータについては Fig. 8 脚注参照. 使用した硫酸化多糖類の種類により親和 性に差が認められた)。

4-2. TAZ 誘導体合成したトリアジン誘導 体 D 及び E の糖認識能についても ITC 実験26)を行 い，いずれも糖認識能（複合体形成能）を有する小 分子であることを確認した。 2 つの化合物の ITC 実験結果は検討した糖誘導体に対する親和性に関す る熱力学的パラメーターが極めて異なる分子である ことも明らかにすることができた（Fig. 9).

ITC の結果から，イソプロポキシ基を有する $C_{3}$ タイプ化合物 $\mathbf{D}$ の糖類との相互作用はエントロ ピー項（一 T $\Delta \mathrm{S} ）$ の寄与が大きく疎水性相互作用

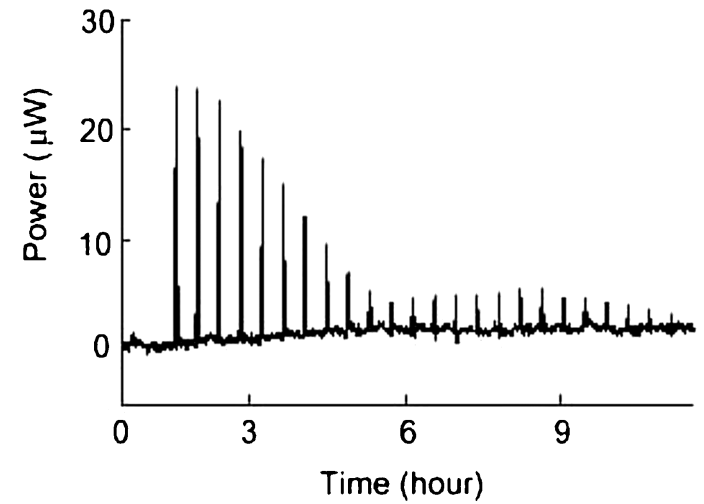

(a)

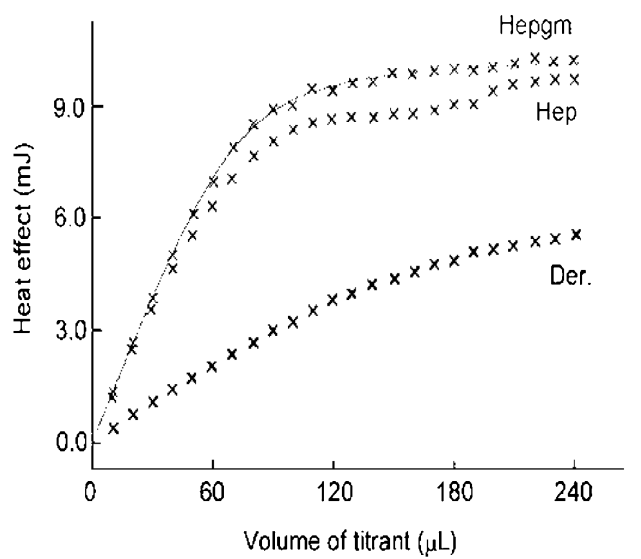

(b)

Fig. 8. (a) Isothermal Titration of a Twin-drug Type Compound 3a with Heparin Sulfate (Hep), and (b) Calculated Fitting Curves for Bivalent Hydantoin Derivative 3a Binding to Heparan Sulfates [Hepgm and Hep] and Dermatan Sulfate $[$ Der $]$

We used dermatan sulfate (GAG-DS01), heparan sulfate (GAG-HS01) and scallop heparan sulfate (GM01/01) as sulfated glycosaminoglycans. In isothermal titration experiments, the binding reaction with GM01/01 [Hepgm] was exothermic and compound 3a showed thermodynamic parameters of $K=4.10 \times 10^{4} \mathrm{M}^{-1}$ and $\Delta H=-9.98 \mathrm{~kJ} / \mathrm{mol}$. Thermodynamic parameters for dermatan sulfate (GAG-DS01) [Der: $K=1.11$ $\times 10^{3} \mathrm{M}^{-1}$ and $\left.\Delta H=-10.9 \mathrm{~kJ} / \mathrm{mol}\right]$ and heparan sulfate (GAG-HS01) [Hep: $K=2.75 \times 10^{4} \mathrm{M}^{-1}$ and $\Delta H=-9.46 \mathrm{~kJ} / \mathrm{mol}$ ] were obtained.

の寄与が大きいことが示唆されたが, ベンジルアミ ン基を有する化合物 E ではエンタルピー $(\Delta \mathrm{H})$ は 大きな負の值をとり，エントロピー項 $(-\mathrm{T} \Delta \mathrm{S})$ の変化は少なく水素結合による相互作用の寄与の大 きいことが示唆された。これらの熱測定結果は，報 告されている熱力学的背景45,46) 考慮すると, アミ

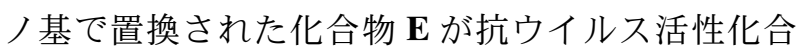
物探索のリード化合物として期待できることを示唆 していると考えている．本化合物の構造変換により 新たに見い出した高い抗 HSV-1 活性を有するオリ ゴバレント構造のハイブリッド型 TAZ 誘導体（例 
Compound D
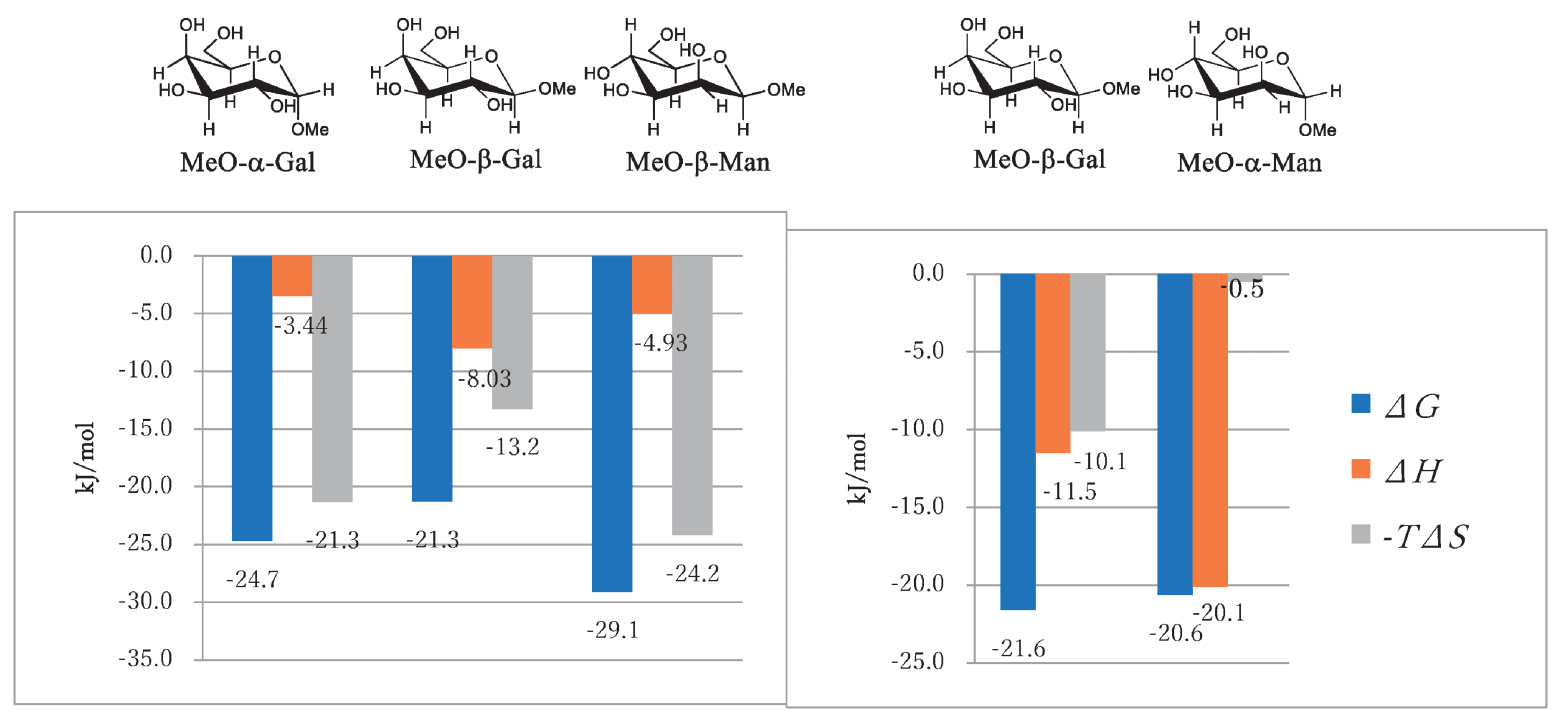

\section{Compound $\mathbf{E} \cdot \mathrm{HCl}$}

Fig. 9. Thermodynamic Signatures for the Binding Reactions of Compounds $\mathbf{D}$ and $\mathbf{E}$ to Sugars

Each of the binding reactions had a $1: 1$ stoichiometry. MeO- $\alpha / \beta$-Gal and MeO- $\alpha / \beta$-Man are abbreviations for methyl $\alpha / \beta$-D-galactopyranoside and methyl $\alpha / \beta$-D-mannopyranoside, respectively. Cited and modified with permission from Mibu N. et al., J. Therm. Anal. Calorim., 135, 2807-2811 (2019) .

えば 15a-4 など）関連誘導体の糖認識能については これからの課題と考えている.

4-3. ボロン酸誘導体糖あるいは第三の生命 鎖としての糖鎖構造中に含有される 1,2-ジオール構 造と特異的に反応して環状のボロン酸エステル類を 形成するボロン酸誘導体の生物活性化合物への応用 は近年に始まった比較的新しい領域である。このよ うな糖類（糖鎖）親和性を有するボロン酸関連誘導 体はいわゆるボロノレクチンと呼ばれる範疇に属す る化合物として考えることができ，関連誘導体は糖 鎖に干渉する機能が期待できる興味ある分子構造の 化合物であり，新しい機序を有する新規な生物活性 リード化合物としての応用も期待できる．合成した 細胞毒性や腫瘍細胞増殖阻害活性を有する前述した 化合物（ビバレント $C_{2}$ 対称性遊離ボロン酸 $\mathbf{2 8 d}$ ) は多くの溶媒に対する溶解性が低く, 現在まだ ITC 実験結果は得ていないが，NMR の手法により 本化合物がある種の糖類に対して親和性を有するこ

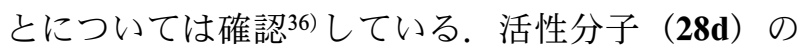
糖 (methyl $\alpha$-D-glucopyranoside) との反応は $1: 2$ の化学量論比の相互作用として解析できたが, 糖認 識の詳細については更なる活性分子探索の展開を含 めて今後の課題と言える.

\section{5. まとめ}

近年，ペプチド関連誘導体のみならず天然物由来
の中分子クラスの範疇（MW: 500-50000）に属す る化合物「 middle-size molecules ( mid-size molecules)」の生物活性が注目されている。本稿で 示したヒダントイン系, トリアジン系あるいはフェ ニルボロン酸系列の多くのオリゴバレント対称性分 子は MW1000 を超えるものも多く新規非ぺプチド 型の中分子31,32) として把握できるものである．対称 性分子という構造特性から，合成標的とする化合物 は中分子クラスの化合物であるにもかかわらずスぺ クトル解析も極めて容易になり学部学生レベルでの 解析も容易となることが多かった。糖類（糖鎖）に 干渉する生物活性分子の探索という側面からの合成 研究を通して，抗菌あるいは抗ウイルス活性さらに は抗腫瘍活性などを示す新しい生物活性中分子を見 い出すことができた．また活性分子のいくつかにつ いては糖認識能を有する化合物であることを確認で き，糖（鎖）関連分野の研究者に幾許かの興味ある 情報を提示できたのではないかと勝手に考えてい る. 抗悪性腫瘍活性においては腫瘍細胞に対する選 択性なども認められ，今後関連誘導体の更なる展開 が期待される.

本稿で紹介した以外にも triarylmethane 類や tris(aminoalkyl) amine 類を基盤とした化合物も合成標 的としたがこれらの結果は今回紹介した文 献20,21,24)に引用されているので興味ある方は文献を 
参照して頂きたい.

謝辞在職中, 研究を推進するあたり多くの方 々のご協力とご指導を受けました。 心より感謝申し 上げます。とくに今回紹介しました標的化合物の探 索合成については藤崎文子博士がヒダントイン類, 壬生伸子博士がトリアジン類, 古舘信博士がボロン 酸類の研究を中心になって, 研究室学生の卒業研究 などに取り入れ学生の指導を担当して頂きました. また，共同研究としての生物活性評価については, 本学微生物薬品化学研究室 見明史雄名誉教授並び に鹿志毛信広教授に抗菌活性評価, 崇城大学薬学部 横溝和美教授及び周 建融博士，上田 勝 熊本大 学名誉教授, 故 宮田 健 熊本大学名誉教授には抗 ウイルス活性評価や細胞毒性, 宮崎大学医学部附属 病院 池田龍二教授及び鹿児島大学病院 武田泰生教 授には抗腫瘍活性評価を頂きました。研究進展とと もに活性評価のみならず多大なご指導とご助言を賜 りました。心より感謝いたします，糖親和性に関す る熱測定実験（ITC）については，本学薬品物理化 学研究室 安藝初美名誉教授及び池田浩人准教授の ご協力とご指導ご助言を頂きました。ここに深謝い たします。先生方には研究過程では適切な助言を賜 り，また研究成果のとりまとめにあたつて多くのご 教示を賜りました。あらためまして深く謝意を表し ます。本学薬学部医薬品化学研究室の同空生，大学 院生として所属された方々など研究室メンバーとは 闊達な議論により学問的探究心と好奇心を刺激さ れ，精神的な支えにもなって頂きました，本当にあ りがとうございました.

利益相反＼cjkstart開示すべき利益相反はない．

\section{REFERENCES}

1) "Essentials of Glycobiology," 3rd ed., ed. by Varki A., Cummings R. D., Esko J. D., Stanley P., Hart G. W., Aebi M., Darvill A. G., Kinoshita T., Packer N. H., Prestegard J. H., Schnaar P. L., Seeberger P. H., Cold Spring Harbor Laboratory Press, Cold Spring Harbor, 2017.

2) Reitsma, S., Slaaf D. W, Vink H., van Zandvoort M. A. M. J., oude Egbrink M. G. A., Pflugers Arch., 454, 345-359 (2007).
3) Sansone F., Casnati A., Chem. Soc. Rev., 42, 4623-4639 (2013).

4) Duran A. M., Meiler J., Comput. Struct. Biotechnol. J., 8, e201308004 (2013).

5) Wermuth C. G. "The Practice of Medicinal Chemistry," 3rd ed., Academic Press, San Diego, 2008.

6) Bérubé G., Curr. Med. Chem., 13, 131-154 (2006).

7) Oshovsky G. V., Reinhoudt D. N., Verboom W., Angew. Chem. Int. Ed., 46, 2366-2393 (2007).

8) Gibson S. E., Castaldi M. P., Angew. Chem. Int. Ed., 45, 4718-4720 (2006).

9) Micewicz E. D., Luong H. T., Jung C.-L., Waring A. J., McBride W. H., Ruchala P. N., Bioorg. Med. Chem. Lett., 24, 1452-1457 (2014).

10) Wittmann V., Curr. Opin. Chem. Biol., 17, 982-989 (2013).

11) Sciore A., Su M., Koldewey P., Eschweiler J. D., Diffley K. A., Linhares B. M., Ruotolo B. T, Bardwell J. C. A., Skiniotis G., Marsh E. N. G., Proc. Natl. Acad. Sci. USA, 113, 86818686 (2016).

12) Cecioni S., Imberty A., Vidal S., Chem. Rev., 115, 525-561 (2015).

13) Furutachi M., Fujisaki F., Tsuru R., Ejima A., Gondo T., Goto S., Ito M., Nakamura M., Aki H., Kashige N., Miake F., Sumoto K., Heterocycles, 92, 1111-1120 (2016).

14) Fujisaki F., Furutachi M., Fujiwara R., Okabe M., Aki H., Kashige N., Miake F., Sumoto K., Heterocycles, 91, 1668-1677 (2015).

15) Fujisaki F., Fujiwara R., Okabe M., Naito A., Fukami E., Aki H., Kashige N., Miake F., Sumoto K., Heterocycles, 89, 2745-2759 (2014).

16) Fujisaki F., Aki H., Naito A., Fukami E., Kashige N., Miake F., Sumoto K., Chem. Pharm. Bull., 62, 429-438 (2014).

17) Fujisaki F., Toyofuku K., Egami M., Ishida S., Nakamoto N., Kashige N., Miake F., Sumoto K., Chem. Pharm. Bull., 61, 10901093 (2013).

18) Fujisaki F., Hiromatsu S., Matsumura Y., Fukami A., Kashige N., Miake F., Sumoto K., J. Heterocycl. Chem., 50, 417-424 (2013). 
19) Furutachi M., Ota K., Fujisaki F., Ikeda R., Yoshikawa N., Yokota T., Takeda Y., Yokomizo K., Zhou J.-R., Kashige N., Miake F., Sumoto K., Biol. Pharm. Bull. 42, 19531956 (2019).

20) Mibu N., Yokomizo K., Uchida W., Takemura S., Zhou J., Aki H., Miyata T., Sumoto K., Chem. Pharm. Bull., 60, 408-414 (2012).

21) Mibu N., Aki H., Ikeda H., Saito A., Uchida W., Yokomizo K., Zhou J., Miyata T., Sumoto K., J. Therm. Anal. Calorim., 113, 10151018 (2013).

22) Mibu N., Yokomizo K., Koga A., Honda M., Mizokami K., Fujii H., Ota N., Yuzuriha A., Ishimaru K., Zhou J., Miyata T., Sumoto K., Chem. Pharm. Bull., 62, 1032-1040 (2014).

23) Mibu N., Yokomizo K., Aki H., Ota N., Fujii H., Yuzuriha A., Saneyoshi S., Tanaka A., Koga A., Zhou J., Miyata T., Sumoto K., Chem. Pharm. Bull., 63, 935-944 (2015).

24) Mibu N., Yokomizo K., Murakami K., Ono Y., Ishimaru M., Otsubo M., Inao H., Ono Y., Zhou J.-R., Sumoto K., Chem. Pharm. Bull., 64, 1769-1780 (2016).

25) Mibu N., Yokomizo K., Sano M., Kawaguchi Y., Morimoto K., Shimomura S., Sato R., Hiraga N., Matsunaga A., Zhou J.-R., Ohata T., Aki H., Sumoto K., Chem. Pharm. Bull., 66, 830-838 (2018).

26) Mibu N., Ohata T., Sano M., Zhou J.-R., Yokomizo K., Aki H., Sumoto K., J. Therm. Anal. Calorim., 135, 2807-2811 (2019).

27) Mibu N., Yokomizo K., Yuzuriha A., Otsubo M., Kawaguchi Y., Sano M., Sakai I., Nakayama K., Zhou J.-R., Sumoto K., Heterocycles, 94, 1653-1677 (2017).

28) Schinazi R. F.. Peters J., Williams C. C., Chance D., Nahmias A. J., Antimicrob. Agents Chemother., 22, 499-507 (1982).

29) Mibu N., Yokomizo K., Yamada K., Matsuyama J., Tomonaga S., Sakai I., Sato R., Kawano Y., Matsumoto Y., Fujita Y., Inoue Y., Iida M., Hashiguchi K., Zhou J.-R., Furutachi M., Sumoto K., Heterocycles, 98, 489-508 (2019).

30) Mibu N., Furutachi M., Inoue Y., Fujita Y., Matsumoto Y., Kawano Y., Tomonaga S., Matsuyama J., Yamada K., Sato R., Yokomi- zo K., Zhou J.-R., Shimomura S., Ota K., Sumoto K., Heterocycles, 98, 1580-1588 (2019).

31) Belema M., Nguyen V. N., Bachand C., Deon D. H., Goodrich J. T., James C. A., Lavoie R., Lopez O. D., Martel A., Romine J. L., Ruediger E. H., Snyder L. B., St. Laurent D. R., Yang F., Zhu J., Wong H. S., Langley D. R., Adams S. P., Cantor G. H., Chimalakonda A., Fura A., Johnson B. M., Knipe J. O., Parker D. D., Santone K. S., Fridell R. A., Lemm J. A., O’Boyle D. R. II, Colonno R. J., Gao M., Meanwell N. A., Hamann L. G., J. Med. Chem., 57, 2013-2032 (2014).

32) DeGoey D. A., Randolph J. T., Liu D., Pratt J., Hutchins C., Donner P., Krueger A. C., Matulenko M., Patel S., Motter C. E., Nelson L., Keddy R., Tufano M., Caspi D. D., Krishnan P., Mistry N., Koev G., Reisch T. J., Mondal R., Pilot-Matias T., Gao Y., Beno D. W. A., Maring C. J., Molla A., Dumas E., Campbell A., Williams L., Collins C., Wagner R., Kati W. M., J. Med. Chem., 57, 20472057 (2014).

33) Bull S. D., Davidson M. G., van den Elsen J. M. H., Fossey J. S., Jenkins A. T. A., Jiang Y.-B., Kubo Y., Marken F., Sakurai K., Zhao J., James T. D., Acc. Chem. Res. , 46, 312-326 (2013).

34) Resendez A., Halim M. A., Landhage C. M., Hellström P. M., Singaram B., Webb D.-L., Clin. Chim. Acta, 439, 115-121 (2015).

35) “Boronic Acids,"' 2nd ed., Vol. 1, ed. by Hall D. G., Wiley-VCH, Weinheim, 2011.

36) Furutachi M., Matsumoto A., Tamenaga T., Sugita A., Kuroiwa M., Yokomizo K., Zhou J.-R., Kashige N., Miake F., Sumoto K., Heterocycles, 96, 1088-1100 (2018).

37) Furutachi M., Ejima A., Tsuru R., Goto S., Gondo T., Ako K., Fuchigami S., Fujii S., Okumura A., Tozuka A., Yokomizo K., Zhou J.-R., Inao H., Ono Y., Kashige N., Miake F., Sumoto K., Heterocycles, 95, 517-524 (2017).

38) Furutachi M., Ejima A., Tsuru R., Goto S., Gondo T., Ako K., Fujii S., Okumura A., Tozuka A., Yokomizo K., Zhou J.-R., Inao H., Ono Y., Kashige N., Miake F., Sumoto K., Heterocycles, 92, 925-935 (2016).

39) Furutachi M., Fujisaki F., Tsuru R., Ejima 
A., Gondo T., Goto S., Ito M., Nakamura M., Aki H., Kashige N., Miake F., Sumoto K., Heterocycles, 92, 1111-1120 (2016).

40) Furutachi M., Fuchigami S., Gondo T., Goto S., Ako K., Sumoto K., Org. Prep. Proced. Int., 49, 287-292 (2017).

41) Furutachi M., Fuchigami S., Ako K., Goto S., Gondo T., Takuse M., Yoshida M., Yokomizo K., Zhou J.-R., Matsunaga A., Hiraga N., Kashige N., Miake F., Sumoto K., Heterocycles, 96, 144-151 (2018).

42) Furutachi M., Gondo T., Goto S., Fuchigami S., Ako K., Oowada Y., Yokomizo K., Zhou J.-R., Ishizaki T., Koga T., Kashige N., Miake
F., Sumoto K., Heterocycles, 94, 1748-1758 (2017).

43) Furutachi M., Gondo T., Ikeda R., Yoshikawa N., Yokota T., Takeda Y., Yokomizo K., Zhou J.-R., Kashige N., Miake F., Sumoto K., Biol. Pharm. Bull., 42, 833-836 (2019) .

44) For example, see the following reference: Vitale D., Katakam S. K., Greve B., Jang B., Oh E.-S., Alaniz L., Götte M., FEBS J., 286, 2870-2882 (2019).

45) Kawasaki Y., Freire E., Drug Discov. Today, 16, 985-990 (2011).

46) Tarcsay Á., Keserü G. M., Drug Discov. Today, 20, 86-94 (2015). 